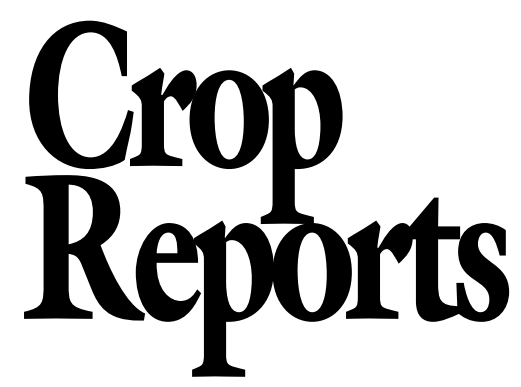

Watercress: A Salad Crop with Chemopreventive Potential

\author{
Usha R. Palaniswamy ${ }^{1}$ and \\ Richard J. McAvoy ${ }^{2}$
}

\begin{abstract}
Additional INDEX wORds. Nasturtium officinale, Rorippa nasturtiumaquaticum, Phen(yl)ethyl isothiocyanate, Cruciferae
\end{abstract}

\section{Classification, origin, and development}

Watercress [Nasturtium officinale (also known as Rorippa nasturtiumaquaticum)] belongs to the family Brassicaceae (Cruciferae). It is a native of southeast Europe (Habegger et al., 1989), probably Germany (Humphrey, 1984) or England (Howard and Lyon, 1952). Watercress is a perennial herbaceous plant reported widely in several parts of Europe, China, New Zealand, and in North America, both as a wild growing species and a cultivated crop. Although described as a medicinal plant since the first century A.D. (Howard, 1976), and valued as a gift fit for royalty (Howard and Lyon

The cost of publishing this paper was defrayed in part by payment of page charges. Under postal regulations, this paper therefore must be hereby marked advertisement to indicate this fact.

${ }^{1}$ School of Allied Health/Asian American Studies Institute, U-2101, University of Connecticut, Storrs, CT-06269-2101; to whom reprint requests should be addressed.

${ }^{2}$ Department of Plant Science, University of Connecti cut, Storrs, CT 06269
1952), its large-scale cultivation did not start until 1750 in Germany, 1808 in England, and 1811 in France (Manton, 1935). Two species of watercress, green watercress (N. officinale) and brown watercress (N. microphyllum), and a sterile hybrid ( $N$. officinale x N. microphyllum) were introduced in about 1850 to New Zealand from England and both species were reported to be growing in Europe and North America (Michaelis, 1976). The Germans and French only cultivated green watercress while the English grew both green watercress and brown watercress on a large scale during the $19^{\text {th }}$ century. However, brown watercress soon was replaced in commercial cultivation by green watercress because of ease of propagation by seeds, and lower susceptibility to the fungal crook root disease caused by Spongospora subterraneasp. nasturtii (Howard and Lyon, 1952). Green watercress appears to be the only species currently cultivated and consumed around the world.

\section{Botanical description and cultivars}

Watercress is a perennial herb with a creeping habit that branches freely. Numerous exogenous adventitious roots are produced at the axils of the leaves under moist and humid growing conditions. Leaves are glabrous, dark green, pinnate, and form about three to six pairs of well-separated leaflets (Fig. 1). It flowers under long day conditions and the inflorescence is a short raceme with small white or yellow flowers that are about 5 to 7 $\mathrm{mm}(0.20$ to 0.28 inches $)$ in diameter. The flowers have four green sepals, four pale yellow or white petals, six stamens, and a solitary pistil. Flowers are self-pollinated, and fruits, elongated capsules, are borne on pedicels, and seeds are produced plentifully (Bleasdale, 1964).

Green watercress is a diploid $(2 \mathrm{n}$ $=32$ ) and the brown watercress is an allotetraploid $(2 \mathrm{n}=64)$, whose other parent may be Cardamine sp. (Howard, 1976). A number of varieties of $N$. officinale have been distinguished in the past including siifolium (1831), microphyllum (1831), and var. parvifolium (1838). However, the two varieties, siifolium and parvifolium, appear to be merely different growth forms of $N$. officinale resulting from moist conditions and from dry conditions respectively (Howard and Lyon, 1952). Though var. microphyllum refers to the tetraploid species (Airy Shaw, 1947), it has been used in the past also to refer to the small-leaved specimens of $N$. officinale as well as to the triploid $(2 \mathrm{n}=48)$ hybrid, $N$. officinale $\times N$. microphyllum.

A number of commercial strains were isolated and selections made for frost resistance, ability to maintain vegetative growth during summer time when watercress normally tends to flower, and for resistance or tolerance to turnip mosaic virus (Bleasdale, 1964; McHugh et al., 1987). However, there has been very little selective and systematic breeding and no standard commercial cultivars seem to have been developed. Many of the selections and commercial strains appear to be unnamed, and the only named strain recorded to be commercially cultivated is Sylvasprings, which was originally developed in England. However, this strain showed a lot of genetic diversity when grown in the United States and was further selected to obtain a homogenous crop stand in the commercial watercress beds.

\section{Production, uses, and composition}

Watercress is a minor crop and the actual area under cultivation is rather difficult to determine, because it is mostly cultivated and marketed locally. Annual consumption of watercress is as low as $110 \mathrm{~g}(3.9 \mathrm{oz})$ per head in the United States (Humphrey, 1984), and its cultivation and consumption as a significant salad crop has declined overtime (Howard, 1976). In the United States, watercress is of considerable economic importance in the state of Hawaii where watercress 


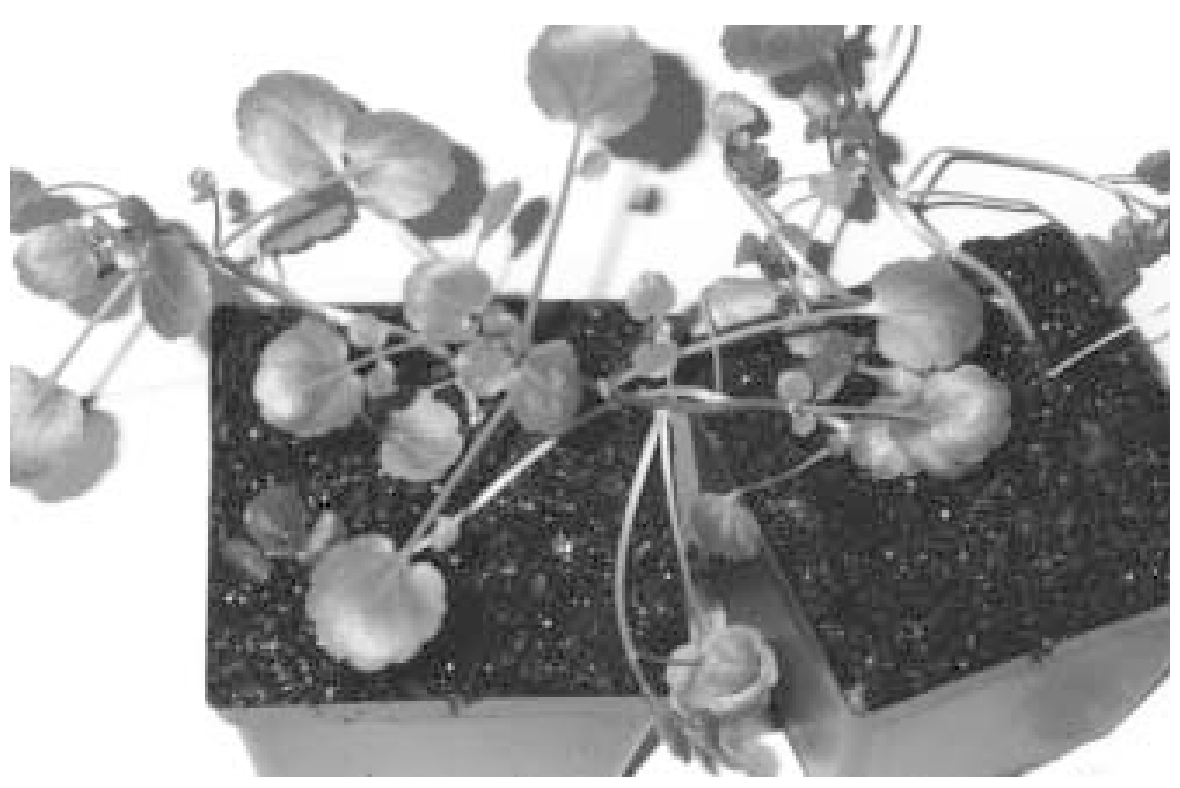

Fig. 1. Watercress (Nasturtium officinale).

was produced on 14.2 ha ( 35 acres) of land in 1985, yielding $695 \mathrm{t}$ (766 tons) with a total farm value of $\$ 1,212,000$ (Hawaii Agricultural Reporting Service, 1985).

More recently, the total area under watercress production increased slightly from 204 ha (505 acres) in 1992, to 246 ha (608 acres) in 1997 (USDA, 1997). Currently it is grown in 122 ha (302 acres) in Florida, 48.6 ha $(120$ acres $)$ in California and in 13.8 ha (34 acres) in Hawaii. Watercress is also grown on private farms in Connecticut, Massachusetts, Virginia and Maryland for which the exact areas under production are withheld to avoid disclosing confidential data.

Watercress has been used as both food and medicine since the first century $\mathrm{AD}$. As a medicinal plant, watercress traditionally has been considered a diuretic, expectorant, purgative, stimulant, stomachic, and tonic. It also has been used as a remedy against anemia, eczema, kidney and liver disorders, tuberculosis, boils, warts, and tumors. The $16^{\text {th }}$ century herbalist Gerarde described watercress soup as a good blood cleanser, and good against scurvy (Humphrey, 1984). Leaf extracts have been used to treat wounds, freckles, and external and internal ulcers. Tender shoots and leaves are used fresh or cooked alone or in mixtures of salad and as a garnish. Though most find the biting peppery taste of watercress leaves rather appealing and its flavor appetizing, some people may find the pungency somewhat objec- tionable and the flavor too strong.

More recently, with increasing interest in healthy diets, the nutritional value of watercress has attracted the attention of a number of scientific investigators and the health-conscious public. Reportedly, watercress has high concentrations of a recently identified chemopreventive of a number of tobacco specific carcinogens-2phen (yl)ethyl isothiocyanate (PEITC) [ $\approx 2$ to $7 \mathrm{mg}^{-1}$ (2,000 to $\left.7,000 \mathrm{ppm}\right)$ leaf dry weight] (Palaniswamy, 1995b, 1997). Watercress is also an excellent source of the antioxidant $\alpha$-tocopherol [0.34 $\mathrm{mg} \mathrm{g}^{-1}(340 \mathrm{ppm})$ fresh weight] (Hadas et al., 1994), and other vitamins and minerals (Table 1) (USDA, 1984).

Watercress possesses glucosinolates and myrosinase, which are characteristic to all crucifers (Kjaer, 1976). Glucosinolate is found in various concentrations throughout the various plant tissues. But the myrosinase enzyme is stored exclusively in special cells that are dispersed throughout the plant. Upon tissue damage, the glucosinolate is hydrolyzed by the myrosinase enzyme to yield isothiocyanates and nitriles (Larsen, 1981; Van Etten and Tookey, 1979). The relative proportion of these two compounds depends on the condition during hydrolysis. In watercress PEITC, and 3-phenylpropionitrile are the predominant hydrolytic products (MacLeod and Islam, 1975; Spence and Tucknott, 1983).

PEITC is the predominant flavor component that imparts the characteristic biting and peppery-hot tastes of watercress (Freeman and Mossadeghi, 1972a). The glucosinolate and the corresponding isothiocyanate in watercress are classic examples of chemical defense (Feeny 1976, 1977). These compounds are deleterious to nonadapted herbivores (Blau et al., 1978) and reduce herbivore damage (Louda and Rodman, 1983) as well as damage by amphipods in water (Newman et al., 1990) during cultivation.

Interest in watercress as a salad vegetable for health promotion and disease prevention has been revived over the past decade because of the many studies that linked the intake of cruciferous vegetables to reduced risk of cancers (Cohen et al., 2000; Joshipura et al., 1999; Osborne, 1999). In particular, the isothiocyanates are reported to be potent inhibitors of carcinogenesis in several animal models (Zhang and Talalay, 1994). Among the crucifer seeds studied, watercress is the most abundant source of gluconasturtin (gluconasturtiin) (the glucosinolate precursor that yields PEITC on hydrolysis), with $5.32 \mathrm{~g}$ of gluconasturtin/100 g of defatted seeds $(53,200 \mathrm{ppm})$ (Daxenbichler et al., 1991). PEITC, inhibited cancers in rats and mice that are caused by several tobacco specific carcinogens including 4-(methylnitrosamino)-1-(3-pyridyl)l-butanone, $\mathrm{N}$-nitrosomethyl benzylamine, benzo(a)pyrene, and $\mathrm{N}$ nitrosobenzylmethyl amine (Siglin et al., 1995; Stoner et al., 1991, 1994; Wattenberg, 1992). PEITC acts as both a blocking agent and an inhibitor of tumor initiation via inhibition of cytochrome $\mathrm{P} 450$ enzymes and by induction of phase II enzymes such as glutathione S-transferases (Meyer et al., 1995).

Steam distilled extracts of watercress containing 3-phenylpropionitrile and 3-phenylpropionic acid were reported to exhibit auxin-like activity and stimulate the elongation of wheat (Triticum aestivum) coleoptiles and garden cress (Lepidium sativum) hypocotyl sections (Wheeler, 1980).

\section{Culture and management}

Watercress can be propagated either from seed or by vegetative means using shoot tip cuttings that root very easily. Until 1955 most watercress was propagated vegetatively, but this prac- 
tice was abandoned to eliminate the spread of turnip mosaic virus (Tomlinson, 1974). Studies show that micropropagation and tissue culture techniques also can be used, and that these methods need to be optimized before use in commercial cultivation (Gilby and Wainwright 1989; Wainwright and Marsh, 1986).

Currently, although tissue-cultured propagules are used for propagation in a few private farms in the United States, seed propagation is still a preferred method in commercial cultivation. Seeds germinate easily, and assure the grower of healthy, virus-free plants in the waterbeds. The color of watercress seeds can vary from pale yellow when freshly harvested to the dark brown of old seeds. Storage at 20 ${ }^{\circ} \mathrm{C}\left(68{ }^{\circ} \mathrm{F}\right)$ and high relative humidity caused the seeds to darken during storage and reduced the dormancy (Biddington et al., 1983). Dark-colored fresh seeds and pale-colored old seeds $(\approx 2$ years old) showed greater germination compared to pale-colored fresh seeds and dark-colored old seeds. Seed germination is best at 10 to 15 ${ }^{\circ} \mathrm{C}\left(50\right.$ to $\left.59{ }^{\circ} \mathrm{F}\right)$ and in the absence of light. Since dormancy of fresh seeds has been often reported, storage of fresh seeds at high temperature $\left[40^{\circ} \mathrm{C}\right.$ (104 $\left.{ }^{\circ} \mathrm{F}\right)$ ] for $3 \mathrm{~d}$ before sowing can be adopted to increase germination rate (Biddington and Ling, 1983). Transplanting healthy seedlings to the watercress beds is preferred to direct sowing in order to ensure an optimal stand and to avoid thinning or filling large areas at a later stage.

Watercress conventionally can be grown in running water (Ryder, 1979), in pots [7 to $8 \mathrm{~cm}$ (2.8 to 3.1 inches) in diameter] with soil medium composed of a mixture of poorly decomposed peat and intensely decomposed peat (Habegger et al., 1989), or in hydroponics with standard Hoagland nutrient solution or nutrient solutions containing the required minerals (Freeman and Mossadeghi, 1972a, 1972b; Palaniswamy et al., 1995a, 1995b). Watercress is reported as a cool-season crop growing well at temperatures of 15 to $25^{\circ} \mathrm{C}\left(59\right.$ to $\left.77^{\circ} \mathrm{F}\right)$ but poorly at higher temperatures (McHugh et al., 1987; Shear, 1949, 1959); however, it can be grown successfully up to temperatures as high as $28{ }^{\circ} \mathrm{C}(82.4$ $\left.{ }^{\circ} \mathrm{F}\right)$ (Palaniswamy, 1998).

Generally watercress plants are grown in water tanks or beds having soil bottoms and moving water. Watercress beds are covered with freely flowing spring water and the plants get most of the nitrogen $(\mathrm{N})$ and other mineral nutrients from the water. Plastic covers protect these commercial beds during winter months to ensure production of watercress year-round for supply in local markets. The waterbeds should be constructed so that surface water or flooded water cannot run through it, because it may damage the bed and the plants. Providing an adequate and good-quality water supply is essential for successful commercial production. Beds of watercress can be maintained for about 10 years without resowing or replanting, and require about 1 month to reach a harvestable stage after a previous harvest. Typically a number of beds are maintained by growers to provide a continuous supply to local markets.

The foundation of outdoor watercress beds may be clay, gravel or crushed stone to provide a firm anchorage to the roots, and also to allow people working in the field to move about while planting, weeding and harvesting (Shear, 1959). The sides of the beds are normally constructed of earth, parted by wood or concrete, ensuring uniform flow of water across the bed. The floor of the waterbeds should be of 5 to $10 \mathrm{~cm}$ ( 2 to 4 inches) of muck.

Watercress fertilized with fertilizer containing a higher proportion of sulfur $(S)$ is reported to yield a more flavorful crop. Hydroponic cultivation gives the grower a chance to obtain and maintain the necessary nutrient levels in the growing medium more precisely to increase yield and flavor. In hydroponics, growing watercress with a higher ratio of $S$ to $N$ can produce leaves of higher concentrations of PEITC and hence a more flavorful product. When grown in closed hydroponic systems containing [in $\left.\mathrm{mg} \cdot \mathrm{L}^{-1}(\mathrm{ppm})\right] 200 \mathrm{~N}$ and 64,128 or $192 \mathrm{~S}$, to yield $\mathrm{N}$ to $\mathrm{S}$ ratios of $1: 0.32,1: 0.64$, or 1:0.96, leaves of watercress plants grown with the $1: 0.64$ $\mathrm{N}$ to $S$ ratio produced $84 \%$ (dry weight basis) more PEITC than those grown with the 1:0.32 $\mathrm{N}$ to $\mathrm{S}$ ratio, while plants grown with the $1: 0.96 \mathrm{~N}$ to $\mathrm{S}$ ratio produced $61 \%$ more PEITC than those grown with the $1: 0.32 \mathrm{~N}$ to $\mathrm{S}$ ratio (Palaniswamy et al., 1995a, 1995b).
Under controlled environmental production with a short photoperiod (8 h), supplemental lighting during the week before produced plants with PEITC concentrations as high as plants exposed to longer photoperiod ( $12 \mathrm{~h}$ ) under similar temperatures (Palaniswamy et al., 1995a, 1995b, $1996,1997)$. When growing watercress in open fields, harvesting plants after l week of bright sunlight may yield more flavorful and healthier produce than if harvested after a period of cloudy days.

\section{Diseases, pests, and management practices}

Diseases noted in watercress include crook root disease, which is a serious problem for watercress growers particularly during the colder months of the year (October to May). The plasmodial fungus (Spongospora subterranean sp. nasturtii) that causes crook root disease also transmits the agents of watercress chlorotic leaf spot, and the yellow spot virus (Tomlinson and Hunt, 1987, Walsh et al., 1989). Maintaining a zinc level of $1.0 \mathrm{mg} \cdot \mathrm{L}^{-1}$ controlled the crook root, the chlorotic leaf spot, and the yellow spot virus (Tomlinson, 1960, 1988).

Leaf spot (Cercospora sp.) that is common during warm and humid seasons can be controlled by spray of tri-

\begin{tabular}{ll}
$\begin{array}{l}\text { Table 1. Nutritional composition of } 100 \\
\text { g(3.53 oz) of edible potion of fresh } \\
\text { watercress. }\end{array}$ \\
\hline Nutrient & Value \\
\hline Water (g) & 95.1 \\
Energy (calories) & 11,000 \\
Protein (g) & 2.3 \\
Fat (g) & 0.1 \\
Carbohydrate (g) & 1.29 \\
Fiber (g) & 0.7 \\
Ca (mg) & 120 \\
P (mg) & 60 \\
Magnesium (mg) & 21 \\
Potassium (mg) & 330 \\
Sodium (mg) & 41 \\
Ascorbic acid (mg) & 43 \\
Thiamin (mg) & 0.09 \\
Riboflavin (mg) & 0.12 \\
Niacin (mg) & 0.20 \\
Pantothenic acid (mg) & 0.31 \\
Vitamin B6 (mg) & 0.13 \\
Vitamin A (International Units) & 4,700 \\
\end{tabular}

${ }^{\text {z}}$ Source USDA, 1984.

y $1.0 \mathrm{~g}=1000 \mathrm{mg}=0.035 \mathrm{oz} ; 1000$ calories $=4.19 \mathrm{~kJ}$; 1 International Unit $=0.6 \mu \mathrm{g}$ of $\beta$-carotene or $1.2 \mu \mathrm{g}$ of other provitamin A carotenoids. 
basic copper sulfate (McHugh et al., 1987). While cultivating in waterbeds, algae can be controlled by 2 to 10 $\mathrm{mg} \cdot \mathrm{L}^{-1}$ copper sulfate. Three species of duckweed (Lemna trisulca, L. minor, and Spirodela polyrbiza), that are prevalent in watercress beds can be controlled by spraying saturated copper sulfate just after the watercress leaves have been cut (Shear, 1959).

Diamondback moth (Plutella xylostella) is a major insect pest in watercress that can be controlled effectively by installing an overhead sprinkler system to disrupt mating and egg laying processes of the adult moth, or by adopting biological control using the parasitic wasp (Cotesia plutella) (McHugh et al., 1987). More recently, high levels of resistance of diamondback moth to Bacillus thuringiensis have been observed. Effective ways suggested to reduce the moth infestation include use of vacuum cleaner to suck the adults (Tanaka, 1992), and the use of nematodes (Steinernema carpocapsae) (Baur et al., 1998) as useful components of integrated pest management programs.

The terrestrial arthropod pest (Gammarus pulex) also feeds on the watercress which can be controlled by using diethyl mercaptosuccinate (Crane et al., 1995). Other minor insect pests include the cyclamen mites (Steneotarsonemus pallidus), cotton aphids (Aphis gossypii), green peach aphids (Myzuz persicae), and turnip aphids (Hyadaphis erysimi).

\section{Harvest and postharvest techniques}

Harvestable watercress plants can be produced in about $35 \mathrm{~d}$ from sowing during summer and about $50 \mathrm{~d}$ during the cooler and darker months. Normally the plants are harvested when they reach a height of $17.8 \mathrm{~cm}(7$ inches) and subsequent harvesting is done at 15 -d intervals.

The concentrations of the flavor component, 2-phen(yl)ethyl glucosinolate and PEITC in the young leaves, is influenced by the stage of harvest as also reported for other crucifers (Bible et al., 1980; Palaniswamy et al., 1995a, $1995 \mathrm{~b}$ ). The harvest stage for optimal flavor corresponds to the stage when the plants have approximately 12 to 15 internodes (about 3 to 4 weeks after transplanting or 6 to 7 weeks after sowing).

Watercress is a perishable leafy salad crop and hence should be shipped and marketed immediately after harvest. The leaves are bunched and precooled before packing in containers that are lined with heavy parchment paper and the layers of watercress are separated by ice. The harvested tender leaves are normally bunched and sold to local consumers.

For best quality maintenance watercress should be kept at $0{ }^{\circ} \mathrm{C}\left(32^{\circ} \mathrm{F}\right)$ and $95 \%$ relative humidity $(\mathrm{RH})$ or above throughout storage and marketing. During transit watercress leaves may be protected from moisture loss, temperature rise and accompanying deterioration by using crushed ice within and around the shipping and storage crates. During retailing and home storage, they need the protection afforded by packaging in moisture-retentive film and by refrigeration. Watercress bunched in polyethylene bags and at $0{ }^{\circ} \mathrm{C}$ and $95 \% \mathrm{RH}$ remained marketable for up to 4 weeks (Hruschka and Wang, 1979).

\section{Literature cited}

Airy Shaw, H.K. 1947. The botanical name of the wild tetraploid watercress. Kew Bul. $1: 38-46$.

Baur, M.E., H.K. Kaya, B.E. Tabashnik, and C.F. Chilcutt. 1998. Suppression of diamondback moth (Lepidoptera: Plutellidae) with an entomopathogenic nematode (Rhabditida: Steinernematidae) and Bacillus thuringiensis Berliner. J. Econ. Entomol. 91:1089-1095.

Bible, B.B., H.Y. Ju, and C. Chong. 1980. Influence of cultivar, season, irrigation and date of planting on thiocyanate content in cabbage. J. Amer. Soc. Hort. Sci. 105:8891 .

Biddington, N.L. and B. Ling. 1983. The germination of watercress (Rorippa nasturtium-aquaticum) seeds. I. The effects of age, storage, temperature light and hormones on germination. J. Hort. Sci. 58:417-426.

Biddington N.L., B. Ling, and R. Dearman.1983. The germination of watercress (Rorippa nasturtium-aquaticum) seeds. II. The relationship between seed color and germination. J. Hort. Sci. 58:427-433.

Blau P.A., P. Feeny, L. Contardo, and D.S. Robson. 1978. Allyglucosinolate and herbivorous caterpillars: A contrast in toxicity and tolerance. Science 200:1296-1298.

Bleasdale, J.K.A. 1964. The flowering and growth of watercress (Nasturtium officinale R. Br.). J. Hort. Sci. 39:277-283.
Cohen J.H., A.R. Kristal, and J.L. Stanford. 2000. Fruit and vegetable intakes and prostate cancer risk. J. Natl. Cancer Inst. 92:6168.

Crane, M., P. Delaney, S. Watson, P. Parker, and C. Walker. 1995. The effect of Malathion 60 on Gammarus pulex (L.) below watercress beds. Environ. Toxicol. Chem. 14:1181-1188.

Daxenbichler, M.E., F.G. Spencer, D.G. Carlson, G.B. Rose, A.M. Brinker, and R.G. Powell. 1991. Glucosinolate composition of seeds from 297 species of wild plants. Phytochemistry 30:2623-2638.

Feeny, P. 1976. Plant apparency [susceptibility to discovery by insects] and chemical defense, Recent Adv. Phytochem. 10:140 .

Feeny, P. 1977. Defensive ecology of the Cruciferae. Ann. Mo. Bot. Garden 64: 221-234.

Freeman, G.G. and N. Mossadeghi. 1972a. Studies on sulfate nutrition and flavor production in watercress (Rorippa nasturtiumaquaticum (L) Hayek). J. Hort. Sci. 47:375-387.

Freeman, G.G. and N. Mossadeghi.1972b. The influence of sulfate nutrition on flavor components of three cruciferous plants, radish (Raphanus sativus) cabbage (Brassica oleracea capitata) and white mustard (Sinapis alba). J. Sci. Food Agr. 23:387402.

Gilby A.C. and H. Wainwright. 1989. Use of tissue culture in improvement of watercress (Rorippa nasturtium-aquaticum L. Hayek). Acta Hort. 244:105-113.

Hadas, S.P., S. Meir, B. Akiri, and J. Kanner. 1994. Oxidative defense systems in leaves of three edible herb species in relation to their senescence rates. J. Agr. Food Chem. 42:2376-2381.

Habegger, R., M. Kohl, and D. Fritz. 1989. A cultivation method for Nasturtium officinale (watercress) grown in green house. Acta Hort. 242:291-295.

Hawaii Agricultural Reporting Service. 1985. Statistics of Hawaiian agriculture. Hawaii Agr. Rpt. Serv., Honolulu.

Howard, H.W. and A.G. Lyon. 1952. Biological flora of the British Isles. Nasturtium officinale R.Br. (Rorippa nasturtiumaquaticum (L.) Hayek). J. Ecol. 40:228238.

Howard, H.W. 1976. Watercress Rorippa nasturtium-aquaticum (Cruciferae) p. 6264. In: N.W. Simmonds (ed.). Evolution of crop plants, Longman, London.

Hruschka, H.W. and C.Y.Wang. 1979. Storage and shelf life of packaged watercress, parsley, and mint. Mkt. Res. Rpt. 
USDA Sci. Educ. Administration. Wash., D.C.

Humphrey, E. 1984. A vegetable with potential. Nutr. Food Sci. 87:20-21.

Joshipura K.J., A. Ascherio, J.E. Manson, M.J. Stampfer, E.B. Rimm, J.E. Speizer, C.H. Hennekens, D. Spiegelman, and W.C. Willett. 1999. Fruit and vegetable intake in relation to risk of ischemic stroke. J. Amer. Medical Assn. 282:1233-1239.

Kjaer, A. 1976. Glucosinolates in the Cruciferae, p. 207-219. In: J.G. Vaughan, A.J. MacLeod, and B.M.G. Jones (eds.). The biology and chemistry of the Cruciferae. Academic Press, New York.

Larsen, P.O. 1981. Glucosinolates, p. 501523. In: P.K. Stumpf and E.E. Conn (eds.). The biochemistry of plants. A comprehensive treatise. vol. 7. Academic Press, New York.

Louda, S.M. and J.E. Rodman. 1983. Ecological patterns in the glucosinolate content of a native mustard, Cardamine cordifolia, in the Rocky Mountains: Insect-plant interactions, chemical defense. J. Chem. Ecol. 9:397-422.

MacLeod A.J. and R. Islam. 1975. Volatile flavour components of watercress. J. Sci. Food Agr. 26:1545-1550.

Manton, I. 1935. The cytological history of watercress (Nasturtium officinale). Zeitschrift fuer Induktive AbstammungsundVererbungslehre. 69:132-157.

McHugh, Jr., J.J., S.K. Fukuda, and K.Y. Takeda. 1987. Hawaii watercress production. Univ. Hawaii, Honolulu, Res. Ext. Ser. 088 .

Meyer, D.J., D.J. Crease, and B. Keterer. 1995. Forward and reverse catalysis and product sequestration by human glutathione S-transferases in the reaction of GSH with dietary aralkyl isothiocyanates. Biochem. J. 306:565-569.

Michaelis, M. 1976. Watercress (Nasturtium microphyllum (Boenn.) Rchb. and $N$. officinale $\mathrm{R}$. Br.) in New Zealand cold springs. Aquatic Bot. 2:317-325.

Newman R.M., W.C. Kerfoot, and Z. Hanscom. 1990. Watercress and amphipods potential chemical defense in a spring stream macrophyte. J. Chem. Ecol. 16:245257

Osborne, M.P. 1999. Chemoprevention of breast cancer. Surgical Clinics of North America 79:1207-1221.

Palaniswamy, U.R. 1998. Enhancement of naturally occurring chemopreventive compounds in salad greens through environmental manipulation during crop growth. PhD diss., Univ. Ct., Storrs.
Palaniswamy, U., R.J. McAvoy, B. Bible, S. Singha, and D.W. Hill. 1995a. Effect of different nitrogen-sulfur ratios on phenethyl isothiocyanate (PEITC) levels in watercress. HortScience 30:789.

Palaniswamy, U., R.J. McAvoy, B. Bible, S. Singha, and D.W. Hill. 1995b. Phenethyl isothiocyanate concentration in watercress (Nasturtium officinale R.Br.) is altered by the nitrogen to sulfur ratio in hydroponic solution, p. 280-283. In: D.L. Gustine and H.E. Flores (eds.). Phytochemicals and health. Amer. Soc. Plant Physiol., Rockville, Md.

Palaniswamy, U., R.J McAvoy, and B. Bible. 1996. The effect of light intensity prior to harvest, on Phenethyl Isothiocyanate (PEITC) levels in watercress (Nasturtium officinale R.Br.), depends on photoperiod. HortScience 31:578.

Palaniswamy, U., R.J. McAvoy, and B. Bible 1997. Supplemental lighting before harvest increases Phenethyl isothiocyanate in watercress under 8-hour photoperiod. HortScience 32:222-223.

Ryder, E.J. 1979. Leafy salad vegetable. Avi Publishing Co. Westport, Ct.

Shear, G.M. 1949. Watercress growing. Va. Agr. Expt. Sta. Bul. 424, Blacksburg, Va.

Shear, G.M. 1959. Growing watercress. USDA, Wash., D.C., Lflt. 448.

Siglin, J.C., D.H. Barch, and G.D. Stoner. 1995. Effects of dietary phenethyl isothiocyanate, ellagic acid, sulindac and calcium, on the induction and progression of N-nitrosomethyl benzylamine induced esophageal carcinogenesis in rats. Carcinogenesis 16:1101-1106.

Spence R.M. and O.G. Tucknott. 1983. Volatiles from the epicuticular wax of watercress (Rorippa nasturtium-aquaticum). Phytochemistry 22:2521-2523.

Stoner, G.D., D.T. Morrissey, Y.H. Heur, E.M. Daniel, A.J. Galati, and S.A. Wagner. 1991. Inhibitory effects of phenethyl isothiocyanate on nitrosobenzylmethylamine carcinogenesis in the rat esophagus. Cancer Res. 51:2063-2068

Stoner, G.D., A.J. Galati, C.J. Schmidt, and M.A Morse. 1994. Inhibition of esophageal tumorigenesis by phenethyl isothiocyanate, p. 173-180. In: M.I. Huang, T. Osawa, T.C.T. Ho, and R.T. Rosen (eds.). Food phytochemicals for chemoprevention. Amer. Chem. Soc., Wash., D.C.

Tanaka, H. 1992. Occurrence of resistance to Bacillus thuringiensis in diamondback moth, and results of trials for integrated control in a watercress greenhouse, p. 165173. In: N.S Talekar (ed.). Diamondback moth and other crucifer pests. Proceedings of the 2nd Intl. Wkshp., 10-14 Dec. 1990, Tainan, Taiwan. Asian Veg.Res. Dev. Ctr. Publ. 92-368, Taipei, Taiwan.

Tomlinson, J. A. 1960. Crook root disease of watercress. A review of research. Natl. Agr. Advisory Serv. Quart. Rev. 49, Wash., D.C.

Tomlinson, J. A. 1974. Research on watercress disease, p. 33-37. In: Symposium on research on the watercress crop, University of Bath, U.K.

Tomlinson, J. A. 1988. Chemical control of Spongospora and Olpidium in hydroponic systems and soil, p. 293-303. In: J.I. Cooper and M.J.C. Asher (eds.). The series analytic: Viruses with fungal vectors. Proc. conference at the University of St. Andrews, 25-27 Aug. 1987, St. Andrews, Scotland.

Tomlinson, J.A. and J. Hunt. 1987. Studies on watercress chlorotic leaf spot virus and on the control of the fungus vector (Spongospora subterranea) with zinc. Ann. Appl. Biol. 110:75-88

U.S. Department of Agriculture. 1984. Composition of foods-Vegetable and vegetable products. Agr. Hdbk. Sect. 11, USDA, Wash., D.C.

U.S. Department of Agriculture. 1997. USDA Natl. Agr. Stat. Serv., AC97. vol 1. USDA, Wash., D.C.

Van Etten, C.H. and H.L. Tookey. 1979. Chemistry and biological effects of glucosinolates, p. 471-500. In: G.A. Rosenthal and D.H. Janzen (eds). Herbivores: Their interaction with secondary plant metabolites. Academic Press, New York.

Wainwright, H. and J. Marsh. 1986. The micropropagation of watercress (Rorippa nasturtium-aquaticum L.). J. Hort. Sci. 61:251-256.

Walsh, J.A., C.M. Clay, A. Miller, and J.C Rowe. 1989. A fungus-transmitted virus of watercress. Aspects Appl. Biol. 22:101108.

Wattenberg, L.W. 1992. Inhibition of carcinogenesis by minor dietary constituents. Cancer Res. 52:2085S-2091S.

Wheeler, A.W. 1980. Auxin-like growth activity of 3-phenylpropionitrile from watercress (Nasturtium officinale R.Br.).Ann. Bot. 46:1-5.

Zhang, Y. and P. Talalay. 1994. Anticarcinogenic activities of organic isothiocyanates: Chemistry and mechanisms. Cancer Res. 54:1976S-1981S 